\title{
First Report of Sexual Reproduction by the Soybean Sudden Death Syndrome Pathogen Fusarium tucumaniae in Nature
}

M. M. Scandiani, Laboratorio Agrícola Río Paraná, San Pedro, Buenos Aires, Argentina; T. Aoki, NIAS Genebank (MAFF), National Institute of Agrobiological Sciences, 2-1-2, Kannondai, Tsukuba, Ibaraki 305-8602 Japan; A. G. Luque, Centro de Referencia de Micología (CEREMIC) Facultad de Ciencias Bioquímicas y Farmacéuticas Universidad Nacional de Rosario, Suipacha 531, Rosario, Argentina; M. A. Carmona, Fitopatología, Facultad de Agronomía, Universidad de Buenos Aires, Av. San Martín 4453 (1417), Ciudad de Buenos Aires, Argentina; and K. O'Donnell, Bacterial Foodborne Pathogens and Mycology Research Unit, NCAUR-ARS-USDA, 1815 N. University St., Peoria, IL 61604 USA

\begin{abstract}
Scandiani, M. M., Aoki, T., Luque, A. G., Carmona, M. A., and O’Donnell, K. 2010. First report of sexual reproduction by the soybean sudden death syndrome pathogen Fusarium tucumaniae in nature. Plant Dis. 94:1411-1416.

Of the four fusaria that have been shown to cause soybean sudden death syndrome (SDS), field surveys indicate that Fusarium tucumaniae is the most important and genetically diverse SDS pathogen in Argentina. Although none of the SDS fusaria have been shown to produce perithecia in nature, a heterothallic sexual cycle has been demonstrated for $F$. tucumaniae via laboratory crosses. Herein we report on the discovery of perithecia of $F$. tucumaniae on soybean in Argentina. Ascospores derived from these perithecia gave rise to colonies that produced sporodochial conidia diagnostic of $F$. tucumaniae. Sporodochial conidia were longer and narrower than those produced by the other SDS fusaria; these conidia also possessed a diagnostic acuate apical cell and a distinctly foot-shaped basal cell. Sixteen strains derived from single ascospores subjected to a validated multilocus genotyping assay (MLGT) for SDS species determination, together with 16 conidial isolates from two sites where teleomorphs were collected, independently confirmed the morphological identification as $F$. tucumaniae. This study represents the first authentic report of sexual reproduction by a soybean SDS pathogen in nature.
\end{abstract}

Since its initial detection in Arkansas in the early 1970s, sudden death syndrome (SDS) of soybean (Glycine max (L.) Merr.) has been reported in all major production areas within North and South America (17). Foliar chlorosis and necrosis, vascular discoloration of stems and roots, root rot, and death are diagnostic features of soybean SDS (17,19). Although initially reported as Fusarium solani (18) or F. solani f. sp. glycines $(7,18)$, the etiological agent in North America is now recognized as $F$. virguliforme, a morphologically and phylogenetically distinct species within clade 2 of the $F$. solani species complex (FSSC) $(3,4,10,14,15)$. Surveys of soybean SDS in Argentina, by way of contrast, surprisingly revealed that four morphologically and phylogenetically distinct fusaria were responsible for SDS in this country (4). Results of an extensive survey

Corresponding author: K. O'Donnell

E-mail: kerry.odonnell@ars.usda.gov

Accepted for publication 16 August 2010.

doi:10.1094/PDIS-06-10-0403

This article is in the public domain and not copyrightable. It may be freely reprinted with customary crediting of the source. The American Phytopathological Society, 2010. demonstrated that Fusarium tucumaniae was the primary etiological agent in five of the six Argentinean provinces sampled, accounting for $87.2 \%(236 / 271)$ of the SDS isolates recovered (14). The three other SDS pathogens ( $F$. virguliforme, $F$. brasiliense, and an undescribed Fusarium sp.) were only recovered in low frequencies in this survey. Koch's postulates have been completed for $F$. virguliforme $(16,18)$, F. tucumaniae (20), F. brasiliense, and an undescribed Fusarium sp. (4).

The available data suggest that the reproductive mode of the main soybean SDS pathogen in North and South America may be different in the two regions. Various molecular markers have revealed a remarkably low level of genetic diversity within isolates of $F$. virguliforme from North America $(2,7,14,19)$, where it is the exclusive cause of soybean SDS, suggesting that its reproductive mode may be strictly clonal (22). In addition, preliminary mating experiments indicated that the isolates of $F$. virguliforme tested all represented a single mating type (5), as expected if this pathogen is reproducing clonally on soybean. In contrast to the lack of genetic diversity observed within collections of $F$. virguliforme, molecular phylogenetic analyses revealed high genetic diversity within $F$. tucumaniae from Ar- gentina and Brazil, suggesting that this species may possess both a clonal and recombining population structure $(3,4)$. Subsequent laboratory crosses successfully demonstrated that $F$. tucumaniae produces a heterothallic teleomorph (5). Multilocus genotyping of the ascosporic progeny analyzed in this study revealed that they were the products of sexual reproduction and recombination. To avoid unnecessary duplication of names promoted by the now antiquated anamorph + teleomorph system, these authors epitypified the teleomorph using the anamorph name, F. tucumaniae, as allowed under Article 59.7 in the Vienna Code of the International Code of Botanical Nomenclature (8).

Except for the initial discovery of the $F$. tucumaniae teleomorph via laboratory crosses (5), there have been no other authentic reports of a SDS pathogen producing perithecia in the laboratory, and none have been observed in nature. Although an anamorph-teleomorph connection was reported based on a culture of a putatively homothallic soybean SDS isolate (IN-2X11B) identified as Nectria haematococca (1), morphological and molecular phylogenetic analyses conducted on this isolate revealed that the teleomorph reported was actually Plectosphaerella cucumerina (anamorph Microdochium tabacinum), a very distant relative of Fusarium in a separate order, the Phyllachorales (12).

The primary objective of the present study is to report on the discovery of sexual reproduction on soybean roots in nature by the SDS pathogen F. tucumaniae in Argentina. Cultures derived from ascospores of the pathogen were characterized morphologically $(3,4)$ and by a validated multilocus genotyping assay for SDS species determination (14).

\section{MATERIALS AND METHODS}

Origin of teleomorph and isolation of single-spored ascosporic cultures. A survey of soybean SDS pathogen diversity was conducted at three different locations in the province of Buenos Aires on 16 March 2010 and at two locations near the town of Hughes in the province of Santa $\mathrm{Fe}$ on 23 April 2010. When the roots were 
examined at $\times 40$ under a dissecting microscope in the laboratory, between 1 and 24 reddish-orange perithecia were discovered near the soil line on six symptomatic plants (Table 1). Microscopic examination with a compound microscope, however, revealed that asci and ascospores were only present in two mature perithecia collected near Pergamino, Fontezuela in the province of Buenos Aires (Fig. 1A to $\mathrm{H}$; GPS coordinate: $33^{\circ} 55^{\prime} 53.13^{\prime \prime} \mathrm{S}$; $\left.60^{\circ} 28^{\prime} 11.19^{\prime \prime} \mathrm{O}\right)$. To confirm that the conidial fungus present on the roots near the perithecia was a SDS-causing Fusarium, blue-green and yellowish conidial masses were mounted in water on microscope slides and examined microscopically. Macroconidia morphologically similar to the SDS-causing fusaria were transferred to sterilized distilled water on a sterile slide and then streaked onto potato dextrose agar (Difco, Detroit, MI) amended with streptomycin (PDAS) and incubated at $25^{\circ} \mathrm{C}$ in the dark. A total of 16 singlespored soybean SDS isolates were cultured from macroconidia; 14 of these were near the mature perithecia on a plant collected at the Pergamino, Fontezuela site and two were near empty perithecia on a plant collected at the Cólón site (Table 1). A Skerman's micromanipulator (21) was used to isolate 16 individual ascospores for culturing from crushed perithecia (Fig. 1A to N) from the Pergamino, Fontezuela site. A total of 16 single-spored ascospore cultures were grown on PDAS. All of the strains reported in this study are available upon request from the CEREMIC Culture Collection (Fac. de Cs. Bioquímicas y Farmacéuticas, UNR) and the Agricultural Research Service Culture Collection (NRRL, NCAUR, Peoria, IL: http://nrrl. ncaur.usda.gov/). All cultures are stored cryogenically in liquid nitrogen vapor at $-175^{\circ} \mathrm{C}$.

Morphological analyses. Detailed phenotypic methods for characterizing macroand micro-morphological characters followed Aoki et al. $(3,4)$. Strains were cultured on synthetic low nutrient agar (SNA) (9) and potato dextrose agar (PDA) in 9$\mathrm{cm}$ plastic petri dishes incubated at $20^{\circ} \mathrm{C}$ under daylight, in complete darkness, or under continuous fluorescent light (Mitsubishi FL40S-W). PDA cultures were used to characterize colony morphology, color, and odor. Colony colors reported in this study follow Kornerup and Wanscher (6).
Colony growth rates were determined using PDA cultures incubated in complete darkness at $20^{\circ} \mathrm{C}(4)$.

Multilocus genotyping. Isolates were cultured in yeast-malt broth as previously described to obtain total genomic DNA from freeze-dried mycelium (11). Protocols for multiplex PCR amplification and species determinations with a Luminex 100 flow cytometer (Austin, TX) followed O'Donnell et al. (14), employing a validated multilocus microsphere array for soybean SDS pathogen identification. Strains of each of the four soybean SDS pathogens, and two closely related Phaseolus root rot pathogens, were included in the assay as positive controls for each species (Table 2). To determine indices of discrimination (ID) for the MLGT identifications, the average intensity of three water negative controls was first subtracted from each value, after which the minimum fluorescence intensity (MFI) was divided by the maximum nontarget fluorescence intensity.

\section{RESULTS}

Species determination based on morphological analysis of perithecia formed in nature and pure cultures of the anamorph derived from single-spored ascospores. Detailed descriptions of the anamorph and teleomorph were published previously $(4,5)$.

Teleomorph morphology formed in nature (Fig. 1A to F): Ascomata solitary or in groups, mostly superficial or surrounded by mycelia, globose, subglobose, ovoid, 122 to $400 \mu \mathrm{m}$ diameter, red in water, yellow in undiluted (ca. 90\%) lactic acid, turning purplish red to dark red in $3 \%$ $\mathrm{KOH}$, nonpapillate or with a papillate neck, ascomata coarsely warted around or above the midregion, warts reddish, up to $80 \mu \mathrm{m}$ high and $70 \mu \mathrm{m}$ wide and composed of a mass of outer ascomatal cells. Cells at ascomatal surface and warts circular to angular, (10-)20-25 $\mu \mathrm{m}$ diameter. Ascomatal wall excluding warts $40-60 \mu \mathrm{m}$ thick, composed of two, outer and inner regions. Paraphyses absent. Periphyses cylindrical, thin-walled. Asci unitunicate, cylindric to clavate, $60-90 \times 8.5-16 \mu \mathrm{m}$, thin-walled, with a basal crozier remnant, containing 8 biserate ascospores arranged obliquely. Ascospores elliptical, oblongelliptical to fusiform-elliptical, 1-septate, often constricted at the central septum when mature, 10-16 $\times 4-6.5 \mu \mathrm{m}$ (means \pm S.D.: $13.1 \pm 1.37 \times 5.1 \pm 0.64 \mu \mathrm{m})$, Length/Width (L/W) 1.9-3.7, hyaline to somewhat pale yellowish, smooth to very minutely rough, thin to somewhat thickwalled.

A specimen consisting of a dried piece of soybean root, containing perithecia formed in nature, from the stem base of a soybean plant exhibiting typical SDS symptoms, collected near Fontezuela (Collection Site, 10-576 M3pl3), in the province of Buenos Aires, Argentina (GPS coordinate: $\left.33^{\circ} 55^{\prime} 53.13^{\prime \prime} \mathrm{S} ; 60^{\circ} 28^{\prime} 11.19^{\prime \prime} \mathrm{W}\right), 16$ March 2010 by M. M. Scandiani, has been deposited in the herbarium of the U.S. National Fungus Collection, Beltsville, MD as BPI 880692.

Anamorphic morphology derived from single ascospores (Fig. $1 \mathrm{G}$ to $\mathrm{N}$ ): Colonies on PDA showing radial mycelial growth rates of $0.9-1.6 \mathrm{~mm}$ per day at $20^{\circ} \mathrm{C}$ in the dark. Colony color on PDA at first white to yellowish-white, later with bluish-gray tint; upon sporulation with conidial pustules of light yellow to greenish-white in the dark, or with conidial pustules of light yellow, grayish-yellow, grayish-green, dark green to dark turquoise under fluorescent light. Aerial mycelium generally sparse and somewhat pionnotal. Colony margin often undulate. Reverse pigmentation absent. Odor absent or moldy. Chlamydospores formed frequently in hyphae and in conidia, subglobose, terminal or intercalary, single or in chains, mostly hyaline, smooth to rough-walled, 7-14 × 5.5-14 $\mu \mathrm{m}$. Sporulation on PDA often light-colored in darkness, greenish to bluish pigmented under fluorescent light; sporodochia normally formed abundantly on SNA and PDA. Aerial conidiophores formed abundantly on SNA, unbranched or sparsely branched, short or long, up to $210 \mu \mathrm{m}$ long, $2.5-5 \mu \mathrm{m}$ wide, forming subulate to subcylindrical monophialides integrated on the apices. Aerial conidia on SNA of two types: (1) curved cylindrical to falcate, (2-)3(-5)septate, with a foot cell, formed mainly on taller conidiophores; (2) minute, oblongellipsoidal to short-clavate, formed on short conidiophores up to $50 \mu \mathrm{m}$ long, $1.5-3 \mu \mathrm{m}$ wide, $0(-1)$-septate, $4-12.5 \times 2-3 \mu \mathrm{m}$ in total range, $6.5-6.9 \times 2.5-2.6 \mu \mathrm{m}$ on average. Sporodochial conidiophores mostly branched verticillately, forming monophialides on the apices. Sporodochial phialides subulate, ampulliform to subcylindric, often

Table 1. Collection data for perithecia recovered from field-grown soybean in Argentina

\begin{tabular}{|c|c|c|c|c|c|}
\hline Origin & Collection no. ${ }^{a}$ & $\begin{array}{l}\text { No. of plants } \\
\text { with perithecia }\end{array}$ & $\begin{array}{c}\text { No. of } \\
\text { perithecia }\end{array}$ & $\begin{array}{l}\text { Perithecium } \\
\text { content }\end{array}$ & Date collected \\
\hline Argentina, Buenos Aires, Cólón & 10-576-M1 & 1 & 2 & Empty & $3 / 17 / 2010$ \\
\hline Argentina, Buenos Aires, Pergamino, Fontezuela & $10-576-\mathrm{M} 3$ & 1 & 24 & Mostly empty & $3 / 17 / 2010$ \\
\hline Argentina, Buenos Aires, Capitán Sarmiento & 10-576-M4 & 2 & 3 & Empty & $3 / 17 / 2010$ \\
\hline Argentina, Santa Fe, Hughes & $10-576-\mathrm{M} 2$ & 1 & 2 & Empty & $3 / 17 / 2010$ \\
\hline Argentina, Santa Fe, Hughes & $10-815$ & 1 & 1 & Empty & $4 / 23 / 2010$ \\
\hline
\end{tabular}

a Plant collection number is that of Mercedes Scandiani. Collection 10-576-M3 represents the plant from which 16 single-spored ascospore and 14 singlespored conidial cultures were derived. 

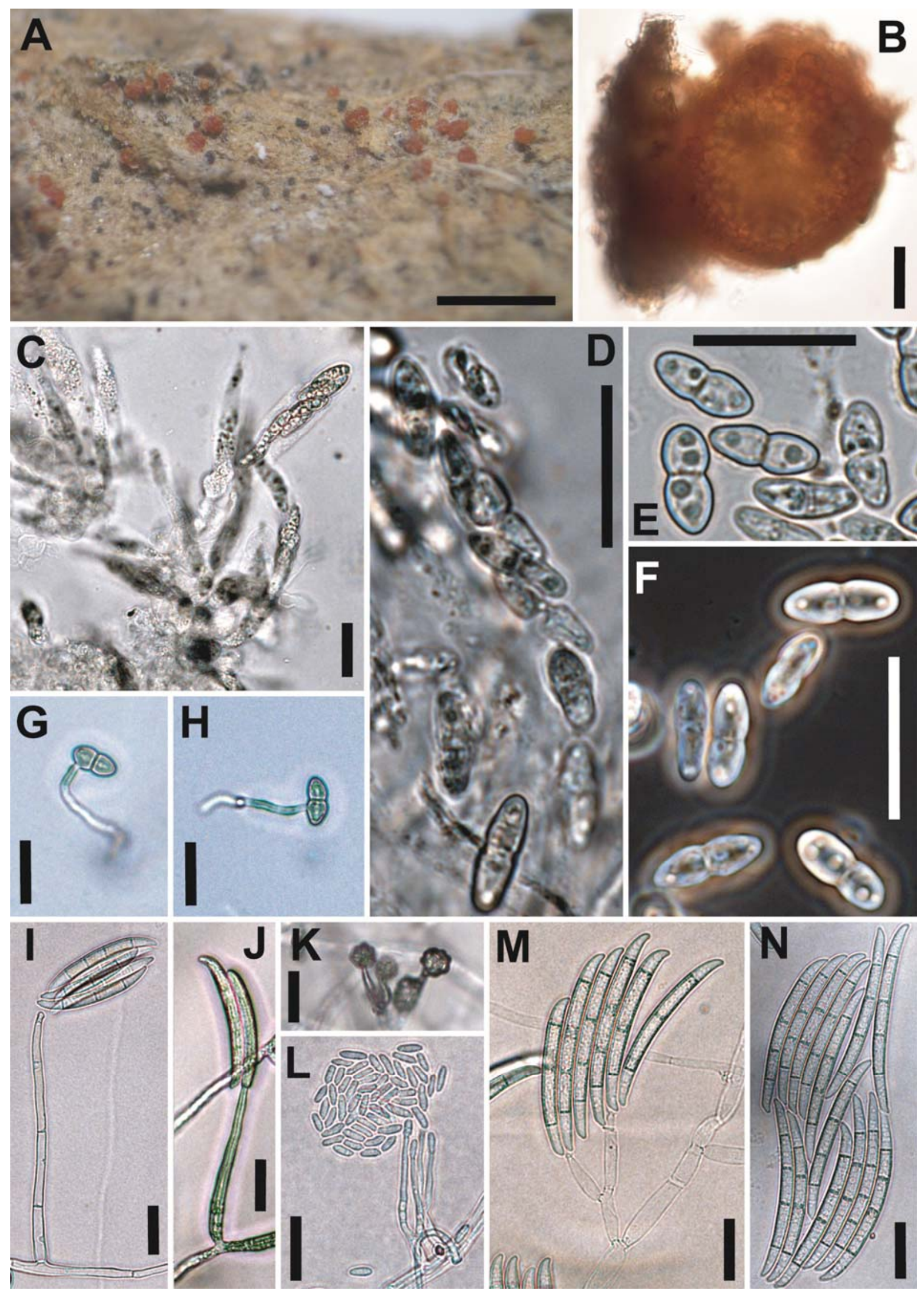

Fig. 1. Ascomata of Fusarium tucumaniae formed in nature and its conidial anamorph produced by colonies derived from germinated ascospores. A and B, Perithecia formed on surface of soybean root exhibiting typical sudden death syndrome (SDS) symptoms, collected at Muestra, province of Buenos Aires, Argentina. C, Mature and immature asci from a crushed perithecium. D, Ascus with eight ascospores. E and F, Two-celled mature ascospores viewed via bright-field (E) and phase-contrast light microscopy (F). G and $\mathbf{H}$, Germinating ascospores isolated from a crushed perithecium. I and J, Falcate multiseptate conidia with a foot cell formed on tall aerial conidiophores on synthetic low nutrient agar (SNA). K and L, Aseptate, short clavate to oblong conidia formed on short aerial conidiophores on SNA. M, Branched sporodochial conidiophore forming falcate multiseptate conidia on SNA. N, Falcate to curved cylindrical conidia with a foot cell formed on SNA. Scale bars = $1 \mathrm{~mm}(\mathbf{A}), 50 \mu \mathrm{m}(\mathbf{B})$, or $20 \mu \mathrm{m}(\mathbf{C}$ to $\mathbf{N})$. I and $\mathbf{M}$ from NRRL 54256, J to $\mathbf{L}$ and $\mathbf{N}$ from NRRL 54255. 
with a conspicuous collarette at the tip. Sporodochial conidia generally cylindrical and gently curved, sometimes falcate, with an acuate apical cell and a distinct basal foot cell, (2-)3-4(-7)-septate; 3-septate on SNA: $36-70 \times 3.5-5.5 \mu \mathrm{m}$ in total range, $55.1-59.2 \times 4.3-4.8 \mu \mathrm{m}$ on average; 4septate on SNA: $53-71.5 \times 3.5-5.5 \mu \mathrm{m}$ in total range, $61.6-64.1 \times 4.4-4.8 \mu \mathrm{m}$ on average; 5-septate on SNA: 57-72 $\times 3.5-$ $5.5 \mu \mathrm{m}$ in total range, $65.3-66.1 \times 4.6-4.9$ $\mu \mathrm{m}$ on average.

Morphological examination of the perithecia (Fig. 1A and B) was made by crushing them on a microscope slide prior to examining them with a compound microscope (Fig. 1C to F). Most of the perithecia examined, however, were immature or empty inside. The ascospore measurements reported above were based on 46 spores recovered from two mature perithecia. Perithecial characters matched the descrip- tion of the F. tucumaniae teleomorph (5), except for ascospore size. Ascospores formed in nature were slightly shorter and narrower than those formed in laboratory crosses (5). The difference in ascospore size presumably was caused by differences in their maturity. Ascospores isolated from the perithecia germinated (Fig. $1 \mathrm{G}$ and $\mathrm{H}$ ) to form aerial conidia and conidiophores (Fig. 1I to L), sporodochial conidia and conidiophores (Fig. 1M and N), and chlamydospores. Anamorphic morphology formed by the single-ascospore isolates matched published descriptions of the $F$. tucumaniae anamorph $(3,4)$. F. tucumaniae can be distinguished from the other soybean SDS pathogens by the production of sporodochial conidia on SNA that are longer and narrower than those produced by the other SDS fusaria. Other distinctive features of $F$. $t u$ cumaniae conidia include a diagnostic acuate apical cell and a distinct basal foot cell.
The cultures obtained from single ascospores were the following: NRRL 54255, NRRL 54256, NRRL 54257, NRRL 54258, NRRL 54259, NRRL 54260, NRRL 54261, NRRL 54262, NRRL 54263, NRRL 54264, NRRL 54265, NRRL 54266, NRRL 54267, NRRL 54268, NRRL 54269, NRRL 54270.

Species determination of ascosporic and conidial cultures using a multilocus genotyping (MLGT) assay. Sixteen cultures derived from single ascospores from perithecia, 14 single-spored conidial cultures derived from a collection near Pergamino, Fontezuela in the province of Buenos Aires, and two conidial cultures derived from the Colón site in Buenos Aires Province where two empty perithecia were collected were genotyped using a validated MLGT assay for soybean SDS species determination. Also included in the assay were 1 to 2 previously characterized

Table 2. Isolates genotyped using a multilocus genotyping (MLGT) assay for soybean sudden death syndrome (SDS) species determination

\begin{tabular}{|c|c|c|c|c|c|c|}
\hline NRRL no. ${ }^{a}$ & $\begin{array}{l}\text { Fusarium } \\
\text { species }^{\text {b }}\end{array}$ & Equivalent no. $^{c}$ & Host & Origin & $\begin{array}{l}\text { Index of } \\
\text { discrimination }^{\mathrm{d}}\end{array}$ & $\begin{array}{l}\text { Year } \\
\text { isolated }\end{array}$ \\
\hline 22276 & F. phaseoli & $\begin{array}{c}\text { van Etten T-162 = MAFF } \\
238544=\text { CCC 189-05 }\end{array}$ & Phaseolus vulgaris & USA & 9 (PH-a), 2 (PH-b) & Unknown \\
\hline 31041 & F. virguliforme & $\mathrm{Li} \# 95$ & Glycine $\max$ & USA, Illinois & $\begin{array}{c}10(96-\mathrm{VI}-1), 4(51- \\
\text { VI-1), } 16 \text { (51-VI-2) }\end{array}$ & 1998 \\
\hline 31104 & F. cuneirostrum & MAFF 305607 & Phaseolus vulgaris & Japan & $2(\mathrm{CU}-\mathrm{a})$ & Unknown \\
\hline 31156 & F. phaseoli & $\begin{array}{l}\text { FRC S- } 1550=\text { MAFF } 238550 \\
=\text { CCC } 190-05\end{array}$ & Phaseolus vulgaris & USA, Michigan & 5 (PH-a), 2 (PH-b) & Unknown \\
\hline 31157 & F. cuneirostrum & $\begin{array}{l}\text { FRC S-1551 = MAFF } 239038 \\
=\text { CCC 192-05 }\end{array}$ & Phaseolus vulgaris & USA, Michigan & $2(\mathrm{CU}-\mathrm{a})$ & 1992 \\
\hline 31757 & F. brasiliense & $\begin{array}{l}\text { Yorinori SDS-5 = MAFF } \\
239050\end{array}$ & Glycine $\max$ & $\begin{array}{l}\text { Brazil, Distiro Federal, } \\
\text { Brasilia }\end{array}$ & 25 (B-a), 3 (B-b) & 1992 \\
\hline 31779 & F. brasiliense & $\begin{array}{c}\text { Yorinori 36/00 = MAFF } \\
239047=\text { CCC 194-05 }\end{array}$ & Glycine $\max$ & $\begin{array}{l}\text { Brazil, Rio Grande do Sul, } \\
\text { Nonai }\end{array}$ & 28 (B-a), 3 (B-b) & 2000 \\
\hline 31781 & F. tucumaniae & Yorinori 41/00 & Glycine $\max$ & Argentina, Tucuman & 6 (TU-a), 8 (TU-c) & Unknown \\
\hline 31949 & Fusarium sp. & $\begin{array}{c}\text { Yorinori 01/00 = MAFF } \\
239052=\text { CCC 198-05 }\end{array}$ & Glycine max & Brazil, Goias, Cristalina & 35 (CR-a), 4 (CR-b) & 2000 \\
\hline 34437 & F. virguliforme & FRC S-1286L = Gray L145 & Glycine $\max$ & USA, Arkansas & $\begin{array}{l}11 \text { (96-VI-1), } 5(51- \\
\text { VI-1), } 17 \text { (51-VI-2) }\end{array}$ & Prior 1993 \\
\hline 36877 & Fusarium sp. & CCC 142-05 & Glycine $\max$ & $\begin{array}{l}\text { Argentina, Santa Fe, } \\
\text { Zavalla }\end{array}$ & 35 (CR-a), 4 (CR-b) & 2004 \\
\hline 54255 & F. tucumaniae & M. Scandiani S-01 (ascospore) & Glycine $\max$ & $\begin{array}{l}\text { Argentina, Buenos Aires, } \\
\text { Pergamino, Fontezuela }\end{array}$ & 8 (TU-a), 10 (TU-c) & 2010 \\
\hline 54256 & F. tucumaniae & M. Scandiani S-02 (ascospore) & Glycine $\max$ & $\begin{array}{l}\text { Argentina, Buenos Aires, } \\
\text { Pergamino, Fontezuela }\end{array}$ & 8 (TU-a), 11 (TU-c) & 2010 \\
\hline 54257 & F. tucumaniae & M. Scandiani S-03 (ascospore) & Glycine max & $\begin{array}{l}\text { Argentina, Buenos Aires, } \\
\text { Pergamino, Fontezuela }\end{array}$ & 8 (TU-a), 11 (TU-c) & 2010 \\
\hline 54258 & F. tucumaniae & M. Scandiani S-04 (ascospore) & Glycine max & $\begin{array}{l}\text { Argentina, Buenos Aires, } \\
\text { Pergamino, Fontezuela }\end{array}$ & 8 (TU-a), 11 (TU-c) & 2010 \\
\hline 54259 & F.tucumaniae & M. Scandiani S-05 (ascospore) & Glycine $\max$ & $\begin{array}{l}\text { Argentina, Buenos Aires, } \\
\text { Pergamino, Fontezuela }\end{array}$ & 8 (TU-a), 10 (TU-c) & 2010 \\
\hline 54260 & F. tucumaniae & M. Scandiani S-06 (ascospore) & Glycine $\max$ & $\begin{array}{l}\text { Argentina, Buenos Aires, } \\
\text { Pergamino, Fontezuela }\end{array}$ & 8 (TU-a), 10 (TU-c) & 2010 \\
\hline 54261 & F. tucumaniae & M. Scandiani S-07 (ascospore) & Glycine $\max$ & $\begin{array}{l}\text { Argentina, Buenos Aires, } \\
\text { Pergamino, Fontezuela }\end{array}$ & 7 (TU-a), 11 (TU-c) & 2010 \\
\hline 54262 & F. tucumaniae & M. Scandiani S-08 (ascospore) & Glycine max & $\begin{array}{l}\text { Argentina, Buenos Aires, } \\
\text { Pergamino, Fontezuela }\end{array}$ & $10(\mathrm{TU}-\mathrm{c})$ & 2010 \\
\hline & & & & & \multicolumn{2}{|c|}{ (continued on next page) } \\
\hline
\end{tabular}

a NRRL = Agriculture Research Service Culture Collection, National Center for Agricultural Utilization Research, USDA-ARS, Peoria, IL.

${ }^{\mathrm{b}}$ Species determination based on anamorph morphology $(3,4)$ and results of the MLGT assay for soybean SDS species determination (14).

${ }^{\mathrm{c}}$ Equivalent no.: $\mathrm{CCC}=$ Culture Collection of CEREMIC (Centro de Referencia de Micología), Fac. de Cs. Bioquímicas y Farmacéuticas, UNR, Rosario, Argentina; FRC = Fusarium Research Center, Department of Plant Pathology, Pennsylvania State University, University Park, PA; MAFF = NIAS Genebank-Microorganisms Section, National Institute of Agrobiological Sciences (NIAS), 2-1-2 Kannondai, Tsukuba, Ibaraki 305-8602, Japan. M. Scandiani S1 to S-16 represent 16 single-spored ascospore derived cultures. CCC 158-10 to CCC 174-10 represent 16 single-spored conidial isolates obtained from field collections of soybean roots bearing perithecia.

${ }^{\mathrm{d}}$ Index of discrimination was determined by first subtracting the average fluorescence intensity of three water negative controls from the value obtained for each DNA sample, and then dividing the minimum fluorescence intensity (MFI) by the maximum nontarget fluorescence intensity. Species-specific primer probes are indicated in parentheses. Probe sequences were reported previously (14). 
positive control strains of the four SDS pathogens (i.e., F. tucumaniae, F. virguliforme, $F$. brasiliense, and Fusarium sp.) and two closely related Phaseolus root-rot pathogens (i.e., F. phaseoli and F. cuenirostrum) (Table 2). Results of the MLGT assay indicated that the 30 isolates collected near Pergamino, Fontezuela and the 2 isolates from Colón were F. tucumaniae. ID values obtained using the F. tucumaniae-specific TU-c probe for all 32 experimental isolates ranged from 7 to 11 , meaning the minimum fluorescent intensity (MFI) values for the $F$. tucumaniae isolates were at least 7 times greater than the MFI values of isolates with a negative genotype. In addition, the $\mathrm{TU}-\mathrm{a}$ probe yielded positive genotypes for 13 of the 32 F. tucumaniae isolates (Table 2). MFI values for the 13 isolates with a positive TU-a genotype ranged from 3 to 8 . Therefore, the MFI values obtained using the TU-a probe were at least 3 times greater than the values for strains with a negative genotype.

\section{DISCUSSION}

Results of the present study provide the first direct evidence of sexual reproduction by a soybean SDS pathogen in nature. Based on the level of DNA polymorphism segregating within $F$. tucumaniae $(3,4)$, Covert et al. (5) hypothesized and subsequently confirmed a sexual cycle in this species employing heterothallic crosses in the laboratory. We hypothesize that $F$. brasiliense may also be recombining sexually within soybean fields in South America, based on the phylogenetic diversity of the isolates sampled to date (14). The available molecular systematic data, however, suggest that $F$. virguliforme may possess a strictly clonal reproduction mode on soybean in North and South America (2-
$4,7,14,19)$. Although $F$. virguliforme was reported to produce a teleomorph in nature (1), subsequent morphological and molecular phylogenetic analyses demonstrated that the reported teleomorph was Plectosphaerella cucumerina, a distantly related homothallic species within the Phyllachorales (12).

The discovery of $F$. tucumaniae perithecia on 6 of the 2,000 roots collected during our 2010 survey for soybean SDS is noteworthy because heterothallic crossing of fusaria is rarely observed in nature. The small number of perithecia detected (i.e., between 1 and 24 per plant), and the fact that all but two were immature or senescent, suggest that conducting surveys earlier and later in the season may contribute to a better understanding of the phenology of teleomorph production under field conditions. It is worth noting that perithecial production by $F$. tucumaniae in the labora-

Table 2. (continued from previous page)

\begin{tabular}{|c|c|c|c|c|c|c|}
\hline NRRL no. ${ }^{a}$ & $\begin{array}{l}\begin{array}{l}\text { Fusarium } \\
\text { species }^{\text {b }}\end{array} \\
\end{array}$ & Equivalent no. ${ }^{\mathrm{c}}$ & Host & Origin & $\begin{array}{l}\text { Index of } \\
\text { discrimination }\end{array}$ & $\begin{array}{l}\text { Year } \\
\text { isolated }\end{array}$ \\
\hline 54263 & F. tucumaniae & M. Scandiani S-09 (ascospore) & Glycine max & $\begin{array}{l}\text { Argentina, Buenos Aires, } \\
\text { Pergamino, Fontezuela }\end{array}$ & $6(\mathrm{TU}-\mathrm{a}), 8(\mathrm{TU}-\mathrm{c})$ & 2010 \\
\hline 54264 & F. tucumaniae & M. Scandiani S-10 (ascospore) & Glycine max & $\begin{array}{l}\text { Argentina, Buenos Aires, } \\
\text { Pergamino, Fontezuela }\end{array}$ & $10(\mathrm{TU}-\mathrm{c})$ & 2010 \\
\hline 54265 & F. tucumaniae & M. Scandiani S-11 (ascospore) & Glycine max & $\begin{array}{l}\text { Argentina, Buenos Aires, } \\
\text { Pergamino, Fontezuela }\end{array}$ & 8 (TU-a), 9 (TU-c) & 2010 \\
\hline 54266 & F. tucumaniae & M. Scandiani S-12 (ascospore) & Glycine max & $\begin{array}{l}\text { Argentina, Buenos Aires, } \\
\text { Pergamino, Fontezuela }\end{array}$ & $12(\mathrm{TU}-\mathrm{c})$ & 2010 \\
\hline 54267 & F. tucumaniae & M. Scandiani S-13 (ascospore) & Glycine max & $\begin{array}{l}\text { Argentina, Buenos Aires, } \\
\text { Pergamino, Fontezuela }\end{array}$ & 9 (TU-c) & 2010 \\
\hline 54268 & F. tucumaniae & M. Scandiani S-14 (ascospore) & Glycine max & $\begin{array}{l}\text { Argentina, Buenos Aires, } \\
\text { Pergamino, Fontezuela }\end{array}$ & $9(\mathrm{TU}-\mathrm{c})$ & 2010 \\
\hline 54269 & F. tucumaniae & M. Scandiani S-15 (ascospore) & Glycine max & $\begin{array}{l}\text { Argentina, Buenos Aires, } \\
\text { Pergamino, Fontezuela }\end{array}$ & 3 (TU-a), 8 (TU-c) & 2010 \\
\hline 54270 & F. tucumaniae & M. Scandiani S-16 (ascospore) & Glycine max & $\begin{array}{l}\text { Argentina, Buenos Aires, } \\
\text { Pergamino, Fontezuela }\end{array}$ & 8 (TU-a), 9 (TU-c) & 2010 \\
\hline 54299 & F. tucumaniae & CCC 158-10 (conidial) & Glycine max & $\begin{array}{l}\text { Argentina, Buenos Aires, } \\
\text { Colón }\end{array}$ & 8 (TU-a), 9 (TU-c) & 2010 \\
\hline 54300 & F. tucumaniae & CCC $159-10$ (conidial) & Glycine max & $\begin{array}{l}\text { Argentina, Buenos Aires, } \\
\text { Colón }\end{array}$ & 7 (TU-a), 9 (TU-c) & 2010 \\
\hline 54301 & F. tucumaniae & CCC 160-10 (conidial) & Glycine max & $\begin{array}{l}\text { Argentina, Buenos Aires, } \\
\text { Pergamino, Fontezuela }\end{array}$ & 9 (TU-c) & 2010 \\
\hline 54302 & F. tucumaniae & CCC $161-10$ (conidial) & Glycine max & $\begin{array}{l}\text { Argentina, Buenos Aires, } \\
\text { Pergamino, Fontezuela }\end{array}$ & $11(\mathrm{TU}-\mathrm{c})$ & 2010 \\
\hline 54303 & F. tucumaniae & CCC $162-10$ (conidial) & Glycine max & $\begin{array}{l}\text { Argentina, Buenos Aires, } \\
\text { Pergamino, Fontezuela }\end{array}$ & $10(\mathrm{TU}-\mathrm{c})$ & 2010 \\
\hline 54304 & F. tucumaniae & CCC $163-10$ (conidial) & Glycine max & $\begin{array}{l}\text { Argentina, Buenos Aires, } \\
\text { Pergamino, Fontezuela }\end{array}$ & 10 (TU-c) & 2010 \\
\hline 54305 & F. tucumaniae & CCC $164-10$ (conidial) & Glycine max & $\begin{array}{l}\text { Argentina, Buenos Aires, } \\
\text { Pergamino, Fontezuela }\end{array}$ & 8 (TU-c) & 2010 \\
\hline 54306 & F. tucumaniae & CCC $165-10$ (conidial) & Glycine max & $\begin{array}{l}\text { Argentina, Buenos Aires, } \\
\text { Pergamino, Fontezuela }\end{array}$ & 9 (TU-c) & 2010 \\
\hline 54307 & F. tucumaniae & CCC $166-10$ (conidial) & Glycine max & $\begin{array}{l}\text { Argentina, Buenos Aires, } \\
\text { Pergamino, Fontezuela }\end{array}$ & $6(\mathrm{TU}-\mathrm{c})$ & 2010 \\
\hline 54308 & F. tucumaniae & CCC $167-10$ (conidial) & Glycine max & $\begin{array}{l}\text { Argentina, Buenos Aires, } \\
\text { Pergamino, Fontezuela }\end{array}$ & 9 (TU-c) & 2010 \\
\hline 54309 & F. tucumaniae & CCC $168-10$ (conidial) & Glycine max & $\begin{array}{l}\text { Argentina, Buenos Aires, } \\
\text { Pergamino, Fontezuela }\end{array}$ & $10(\mathrm{TU}-\mathrm{c})$ & 2010 \\
\hline 54310 & F. tucumaniae & CCC $170-10$ (conidial) & Glycine max & $\begin{array}{l}\text { Argentina, Buenos Aires, } \\
\text { Pergamino, Fontezuela }\end{array}$ & 9 (TU-c) & 2010 \\
\hline 54311 & F. tucumaniae & CCC $171-10$ (conidial) & Glycine max & $\begin{array}{l}\text { Argentina, Buenos Aires, } \\
\text { Pergamino, Fontezuela }\end{array}$ & 9 (TU-c) & 2010 \\
\hline 54312 & F. tucumaniae & CCC $172-10$ (conidial) & Glycine max & $\begin{array}{l}\text { Argentina, Buenos Aires, } \\
\text { Pergamino, Fontezuela }\end{array}$ & $10(\mathrm{TU}-\mathrm{c})$ & 2010 \\
\hline 54313 & F. tucumaniae & CCC $173-10$ (conidial) & Glycine max & $\begin{array}{l}\text { Argentina, Buenos Aires, } \\
\text { Pergamino, Fontezuela }\end{array}$ & 8 (TU-c) & 2010 \\
\hline 54314 & F. tucumaniae & CCC 174-10 (conidial) & Glycine max & $\begin{array}{l}\text { Argentina, Buenos Aires, } \\
\text { Pergamino, Fontezuela }\end{array}$ & 7 (TU-c) & 2010 \\
\hline
\end{tabular}


tory, in which mature ascospores were oozing from the ostioles, takes at least 30 days when incubated at $18^{\circ} \mathrm{C}$ under continuous fluorescent illumination (5).

Although the morphological data we obtained on the perithecia collected in nature matched the protologue of $F$. tucumaniae (5), definitive identification of the teleomorph was made possible by conducting detailed morphological analyses of the conidial anamorph produced by colonies derived from single-spored ascospores isolated from the perithecia collected near Pergamino, Fontezuela in the province of Buenos Aires. Consistent with prior descriptions of this species $(3,4)$, the ascosporic isolates produced sporodochial conidia that were longer and narrower than those produced by the three other SDS fusaria. In addition, conidia produced by the F. tucumaniae isolates also possessed a diagnostic acuate apical cell and a distinct basal foot cell.

Independent identification of the 16 ascosporic and 16 conidial isolates as $F$. tucumaniae was obtained using a validated multilocus genotyping assay for soybean SDS species determination (14; Table 2). In contrast to the original report, in which the F. tucumaniae-specific TU-a and TU-c probes performed equally well (14), the TU-c probe outperformed the TU-a probe in the present study. In anticipation of this problem, redundant species-specific probes were incorporated into the SDS MLGT assay, and in similar suspension microsphere arrays for human pathogenic fusaria (13) and an assay for Fusarium head blight species identification and trichothecene chemotype determination (23). Because the primer probes in these molecular diagnostic assays were all designed based on known species-specific DNA sequence variation within the locus targeted, information gained from sequencing the region where the TU-a probe primes within locus 51 , in the isolates that yielded a negative genotype, should prove to be invaluable in the redesign of this probe.

Given the high throughput platform provided by the soybean SDS MLGT assay (14), it is particularly well suited for monitoring changes in soybean SDS species diversity in North and South America. In addition, this assay should be beneficial to quarantine and plant inspection officials charged with preventing the inadvertent or intentional introduction of foreign pathogens such as $F$. tucumaniae into the United States. In contrast to $F$. virguliforme, which appears to be strictly clonal on soybean in both hemispheres, a sexually reproducing pathogen such as $F$. tucumaniae is more likely to overcome multilocus quantitative resistance within soybean (5). As such, knowledge of the soybean SDS pathogens' reproductive mode has practical implications for the management of this disease.

\section{ACKNOWLEDGMENTS}

We thank Stacy Sink for expert technical assistance in running the MLGT assay. The mention of trade products does not imply that they are endorsed or recommended by the U.S. Department of Agriculture over other firms or similar products not mentioned.

\section{LITERATURE CITED}

1. Abney, T. S., Richards, T. L., and Roy, K. W. 1993. Fusarium solani from ascospores of Nectria haematococca causes sudden death syndrome of soybean. Mycologia 85:801806.

2. Achenbach, L. A., Patrick, J., and Gray, L. 1996. Use of RAPD markers as a diagnostic tool for the identification of Fusarium solani isolates that cause soybean sudden death syndrome. Plant Dis. 80:1228-1232.

3. Aoki, T., O'Donnell, K., Homma, Y., and Lattanzi, A. R. 2003. Sudden death syndrome of soybean is caused by two morphologically and phylogenetically distinct species within the Fusarium solani species complex $-F$. virguliforme in North America and F. tucumaniae in South America. Mycologia 95:660-684.

4. Aoki, T., O'Donnell, K., and Scandiani, M. M. 2005. Sudden death syndrome of soybean in South America is caused by four species of Fusarium: Fusarium brasiliense sp. nov., F. cuneirostrum sp. nov., F. tucumaniae, and $F$. virguliforme. Mycoscience 46:162-183.

5. Covert, S. F., Aoki, T., O'Donnell, K., Starkey, D., Holliday, A., Geiser, D. M., Cheung, F., Town, C., Strom, A., Juba, J., Scandiani, M., and Yang, X. B. 2007. Sexual reproduction in the sudden death syndrome pathogen Fusarium tucumaniae. Fungal Genet. Biol. 44:799807.

6. Kornerup, A., and Wanscher, J. H. 1978. Methuen Handbook of Colour, 3rd ed. Methuen, London.

7. Li, S., Tam, Y.-K., and Hartman, G. L. 2000. Molecular differentiation of Fusarium solani $\mathrm{f}$. sp. glycines from other $F$. solani based on mitochondrial small subunit rDNA sequences. Phytopathology 90:491-497.

8. McNeill, J., Barrie, F. R., Burdet, H. M., Demoulin, V., Hawksworth, D. L., Marhold, K., Nicolson, D. H., Prado, J., Silva, P. C., Skog, J. E., Wiersema, J. H., and Turland, N. J. 2006. International Code of Botanical Nomenclature (Vienna Code). Regnum Vegetabile, vol. 146. Gantner Verlag, Ruggell, Liechtenstein.

9. Nirenberg, H. I. 1990. Recent advances in the taxonomy of Fusarium. Stud. Mycol. 32:91101.

10. O'Donnell, K. 2000. Molecular phylogeny of the Nectria haematococca-Fusarium solani species complex. Mycologia 92:919-938.

11. O'Donnell, K., Cigelnik, E., and Nirenberg, H. 1998. Molecular systematic and phylogeography of the Gibberella fujikuroi species complex. Mycologia 90:465-493.
12. O'Donnell, K., and Gray, L. E. 1995. Phylogenetic relationships of the soybean sudden death syndrome pathogen Fusarium solani f. sp. phaseoli inferred from rDNA sequence data and PCR primers for its identification. Mol. Plant-Microbe Interact. 8:709-716.

13. O'Donnell, K., Sarver, B. A. J., Brandt, M., Chang, D. C., Noble-Wang, J., Park, B. J., Sutton, D. A., Benjamin, L., Lindsley, M., Padhye, A., Geiser, D. M., and Ward, T. J. 2007. Phylogenetic diversity and microsphere arraybased genotyping of human pathogenic fusaria, including isolates from the multistate contact lens-associated U.S. keratitis outbreaks of 2005 and 2006. J. Clin. Microbiol. 45:22352248.

14. O'Donnell, K., Sink, S., Scandiani, M. M., Luque, A., Colletto, A., Biasoli, M., Lenzi, L., Salas, G., González, V., Ploper, L. D., Formento, N., Pioli, R. N., Aoki, T., Yang, X. B., and Sarver, B. A. J. 2010. Soybean sudden death syndrome species diversity within North and South America revealed by multilocus genotyping. Phytopathology 100:58-71.

15. O'Donnell, K., Sutton, D. A., Fothergill, A., McCarthy, D., Rinaldi, M. G., Brandt, M. E., Zhang, N., and Geiser, D. M. 2008. Molecular phylogenetic diversity, multilocus haplotype nomenclature, and in vitro antifungal resistance within the Fusarium solani species complex. J. Clin. Microbiol. 46:2477-2490.

16. Roy, K. W., Lawrence, G. W., and McLean, K. S. 1989. Isolation and identification of Fusarium solani, the cause of sudden death syndrome of soybean. Plant Diagn. Quart. 10:17 27.

17. Roy, K. W., Rupe, J. C., Hershman, D. E., and Abney, T. S. 1997. Sudden death syndrome of soybean. Plant Dis. 81:1100-1111.

18. Rupe, J. C. 1989. Frequency and pathogenicity of Fusarium solani recovered from soybeans with sudden death syndrome. Plant Dis. 73:581-584.

19. Rupe, J. C., Correll, J. C., Guerber, J. C., Becton, C. M., Gbur, E. E., Cummings, M. S., and Yount, P. A. 2001. Differentiation of the sudden death syndrome pathogen of soybean, Fusarium solani f. sp. glycines, from other isolates of $F$. solani based on cultural morphology, pathogenicity, and mitochondrial DNA restriction fragment length polymorphisms. Can. J. Bot. 79:829-835

20. Scandiani, M., Ruberti, D., O'Donnell, K. Aoki, T., Pioli, R., Giorda, L., Luque, A., and Biasoli, M. 2004. Recent outbreak of soybean sudden death syndrome caused by Fusarium virguliforme and F. tucumaniae in Argentina. Plant Dis. 88:1044.

21. Skerman, V. B. D. 1968. A new type of micromanipulator and microforge. J. Gen. Microbiol. 54:287-297.

22. Taylor, J. W., Jacobson, D. J., and Fisher, M. C. 1999. The evolution of asexual fungi: Reproduction, speciation and classification. Annu. Rev. Phytopathol. 37:197-246.

23. Ward, T. J., Clear, R. M., Rooney, A. P., O’Donnell, K., Gaba, D., Patrick, S., Starkey, D. E., Gilbert, J., Geiser, D. M., and Nowicki, T. W. 2008. An adaptive evolutionary shift in Fusarium head blight pathogen populations is driving the rapid spread of more toxigenic Fusarium graminearum in North America. Fungal Genet. Biol. 45:473-484. 